\title{
PENGARUH SUHU DAN KONSENTRASI LARUTAN GULA TERHADAP PROSES DEHIDRASI OSMOSIS BUAH PISANG KEPOK MENGKAL (MUSA PARADISIACA FORMA TYPICA)
}

\section{(Effect of Temperature and Sugar Liquid Concentration on Osmosis Dehidration Process of Banana Fruit (Musa Paradisiaca Forma Typica))}

\author{
Andyka Saputra ${ }^{1 *}$, Mursalim ${ }^{2)}$, dan Supratomo ${ }^{3)}$ \\ ${ }^{1)}$ Program Studi Teknik Pertanian, Universitas Hasanuddin, Makassar \\ ${ }^{2)}$ Program Studi Teknik Pertanian, Universitas Hasanuddin, Makassar \\ ${ }^{3}$ Program Studi Teknik Pertanian, Universitas Hasanuddin, Makassar \\ *) Email korespondensi: Andykasaputra92@gmail.com
}

\begin{abstract}
ABSTRAK
Dehidrasi Osmosis merupakan salah satu bentuk pretreatment pada bahan makanan. Penelitian ini bertujuan untuk menentukan perlakuan yang terbaik dalam proses dehidrasi osmosis pada buah pisang kepok mengkal. Buah pisang kepok mengkal akan direndam selama 5 jam dengan pengaruh suhu $40^{\circ} \mathrm{C}, 50^{\circ} \mathrm{C}$ dan $60^{\circ} \mathrm{C}$. Dan dengan pengaruh konsentrasi larutan gula 50 Brix, 60 Brix dan 70 Brix. Perlakuan suhu $60^{\circ} \mathrm{C}$ dan konsentrasi larutan gula 70 Brix menghasilkan kadar air yang paling rendah yakni sebesar $33.59 \%$ basis basah, Weight Reduction (WR) yang paling tinggi yakni sebesar 1.1947 dan efektivitas yang paling tinggi yakni sebesar 1.1116. Adapun pada perlakuan suhu $60^{\circ} \mathrm{C}$ secara individu menghasilkan Solid Gain (SG) yang paling rendah sebesar $2.79 \mathrm{~g}$ dan perlakuan konsentrasi larutan gula 60 Brix secara individu menghasilkan Solid Gain (SG) yang paling rendah yakni sebesar $2.83 \mathrm{~g}$. Perlakuan konsentrasi larutan gula 70 Brix secara individu menghasilkan Water Loss (WL) yang paling tinggi sebesar $1.16 \mathrm{~g}$.
\end{abstract}

Kata Kunci: Dehidrasi Osmosis, Pisang Kepok, Suhu, Konsentrasi Larutan Gula.

PENDAHULUAN

\section{Latar Belakang}

Pisang menjadi salah satu buah yang banyak digemari oleh masyarakat di seluruh dunia. Produksi pisang dunia pada tahun 2014 sebesar 18,6 miliar ton (FAO, 2017). Buah pisang mudah dijumpai di beberapa negara yang beriklim tropis seperti Thailand, Brazil dan juga Indonesia. Di Indonesia, terdapat berbagai jenis pisang dan semua jenis pisang tersebut, menjadi favorit konsumsi masyarakat di seluruh daerah di Indonesia, terdapat pisang yang dapat dikonsumsi secara langsung dan adapula pisang yang perlu diproses terlebih dahulu, seperti buah pisang kepok.
Buah pisang kepok menjadi salah satu komoditi yang mudah rusak, hal tersebut terjadi akibat beberapa faktor, seperti: aktivitas dan pertumbuhan mikroba pada buah pisang, aktivitas enzim-enzim didalam buah pisang, perlakuan suhu, serta beberapa faktor lainnya yang dapat merusak buah pisang. Sehingga, perlu diberikan metode pengawetan untuk mencegah kerusakan bahan pangan, salah satunya dengan metode dehidrasi osmosis. Dehidrasi osmosis menjadi salah satu metode untuk mengurangi kadar air dalam bahan pangan. Dengan cara perendaman pada larutan berkonsentrasi tinggi. Dengan metode dehidrasi osmosis, bahan pangan yang direndam akan mengalami penurunan bobot. Hal tersebut terjadi karena cairan yang 
terdapat di dalam bahan pangan keluar dan zat terlarut dari larutan masuk ke dalam bahan pangan. Bahan pangan yang dihasilkan dari proses ini memiliki kelebihan dibandingkan metode pengawetan bahan pangan lainnya yakni, antara lain: meningkatkan kualitas produk bahan makanan yang diawetkan, memberikan kisaran kadar air dan zat terlarut bahan yang diinginkan untuk pengolahan pangan, meminimalisasi

stress karena panas dan mengurangi input energi pada pengeringan konvensional (Witono dkk., 2013).

Berdasarkan pemaparan di atas, maka perlu dilakukan penelitian tentang pengaruh suhu dan konsentrasi larutan gula terhadap proses dehidrasi osmosis buah pisang kepok mengkal (Musa paradisiaca forma typica) untuk mempelajari dan mengetahui proses dehidrasi osmosis pada buah pisang kepok mengkal, dengan mengukur parameter pengukuran selama proses berlangsung.

\section{Tujuan dan Kegunaan}

Tujuan dari penelitian ini adalah untuk mempelajari dan mengetahui proses dehidrasi osmosis pada buah pisang kepok mengkal.

Kegunaan dari penelitian ini adalah sebagai acuan dalam proses pretreatment buah pisang kepok mengkal.

\section{METODE PENELITIAN}

Alat

Alat yang digunakan pada penelitian ini adalah water bath, texture analyzer, refraktometer, oven, desikator, gelas breaker 2 L, sendok, cawan, timbangan analitik, wadah plastik, termometer, pisau dan talenan.

\section{Bahan}

Bahan yang digunakan pada penelitian ini adalah pisang kepok mengkal, gula kristal, aquades, plastik, kertas tisu, kertas label dan aluminium foil.

\section{Prosedur Penelitian}

Rancangan penelitian yang digunakan adalah Rancangan Acak Kelompok (RAK) yang disusun secara faktorial dengan 2 faktor. Faktor I terdiri dari 3 level dan faktor II terdiri dari 3 level dengan 3 kali ulangan.

Faktor tersebut adalah:

Faktor I: Konsentrasi larutan gula

$\mathrm{K} 1=50$ Brix

$\mathrm{K} 2=60$ Brix

$\mathrm{K} 3=70$ Brix

Faktor II: Suhu perendaman

$\mathrm{T} 1=40^{\circ} \mathrm{C}$

$\mathrm{T} 2=50^{\circ} \mathrm{C}$

$\mathrm{T} 3=60^{\circ} \mathrm{C}$

Tabel 1. Perlakuan suhu dan konsentrasi pada larutan osmosis.

\begin{tabular}{|c|c|c|}
\hline \multicolumn{2}{|c|}{ Perlakuan } & \multirow{2}{*}{$\begin{array}{c}\text { Notasi } \\
\text { Perlakuan } \\
\end{array}$} \\
\hline Suhu Larutan & Konsentrasi & \\
\hline \multirow{3}{*}{$40^{\circ} \mathrm{C}$} & 50 Brix & T1K1 \\
\hline & 60 Brix & T1K2 \\
\hline & 70 Brix & T1K3 \\
\hline \multirow{3}{*}{$50^{\circ} \mathrm{C}$} & 50 Brix & $\mathrm{T} 2 \mathrm{~K} 1$ \\
\hline & 60 Brix & T2K2 \\
\hline & 70 Brix & T2K3 \\
\hline \multirow{3}{*}{$60^{\circ} \mathrm{C}$} & 50 Brix & T3K1 \\
\hline & 60 Brix & T3K2 \\
\hline & 70 Brix & T3K3 \\
\hline
\end{tabular}

Prosedur kerja dari penelitian ini adalah:

\section{Penyiapan Sampel}

Tahap dalam penyiapan sampel penelitian sebagai berikut

(Sharma et al., 2000):

1. Menyiapkan alat dan Bahan

2. Mengupas kulit pisang dan memotong pisang dengan berat \pm 5 gram dengan tebal $\pm 0.5 \mathrm{~cm}$.

3. Memberi tanda pada masing-masing sampel.

4. Meletakkan hasil potongan buah pisang pada wadah dan menutupnya dengan plastik.

\section{Pengukuran kekerasan bahan}

Adapun tahap pengukuran kekerasan bahan yakni:

1. Menyiapkan alat dan bahan

2. Memasukkan plat kosong ke dalam platform.

3. Menempatkan pisang mengkal di piring kosong dan posisikan secara terpusat di bawah probe. Memulai uji penetrasi di sekitar bagian tengah buah pada kedalaman $1,5 \mathrm{~cm}$.

4. Melihat hasil pengukuran pada desktop. 


\section{Penyiapan Larutan Osmosis}

Adapun tahap-tahap dalam menyiapkan larutan osmosis yakni, sebagai berikut (Kartika dan Nisa, 2015):

1. Menyiapkan alat dan Bahan

2. Memasukkan gula sedikit demi sedikit ke dalam gelas breaker yang telah berisi $1 \mathrm{~L}$ aquades.

3. Mengukur konsentrasi 50 Brix, 60 Brix dan 70 Brix pada larutan, dengan menggunakan refraktometer.

\section{Proses dehidrasi osmosis}

Adapun tahap-tahap dalam perendaman sampel dengan larutan gula yakni, sebagai berikut (Sharma et al., 2000):

1. Menyiapkan alat dan bahan.

2. Memasukkan 2 L larutan osmosis 50 Brix kedalam gelas breaker.

3. Memasukkan 20 potongan sampel ke dalam larutan osmosis 50 Brix. Lalu, larutan ditutup dengan aluminium foil, untuk mencegah air masuk kedalam gelas kimia selama proses berlangsung.

4. Memasukkan gelas breaker yang berisi larutan dan sampel ke dalam sebuah water bath, yang dipertahankan pada suhu $40^{\circ} \mathrm{C}$

5. Mengambil satu sampel, setiap interval waktu 30 menit sampai 5 jam.

6. Menimbang dan mencatat sampel yang telah direndam.

7. Mengulangi prosedur 1 sampai 5 dengan suhu $50^{\circ} \mathrm{C}$ dan $60^{\circ} \mathrm{C}$ dan pada konsentrasi 60 Brix dan 70 Brix.

\section{Parameter Pengukuran}

Adapun parameter yang akan diukur yakni, antara lain (Sharma et al., 2000):

\section{Kadar air}

Pengukuran kadar air dilakukan dengan metode gravimetrik/oven yaitu dilakukan dengan memasukkan sampel sebelum perendaman kedalam cawan yang telah ditimbang untuk mendapatkan data berat awal $\left(\mathrm{W}_{0 \mathrm{x}}\right)$. Setelah itu, dimasukkan dalam oven hingga bobot konstan selama 24 jam pada suhu $105^{\circ} \mathrm{C}$. Lalu, bahan dikeluarkan dan dimasukkan kedalam desikator selama 15 menit, kemudian ditimbang untuk memperoleh berat sampel kering $\left(\mathrm{S}_{\mathrm{x}}\right)$. Data yang diperoleh, kemudian diolah dengan rumus di bawah:

Keterangan:

$$
\mathrm{Mx}=\frac{\mathrm{W} 0 \mathrm{x}-\mathrm{Sx}}{\mathrm{W} 0 \mathrm{x}} \times 100 \%
$$

Mx : Kadar air basis basah pada sampel $\mathrm{x}$ $(\%)$.

W0x : Berat sampel $x$ awal pisang (g).

Sx : Berat sampel $\mathrm{x}$ kering $(\mathrm{g})$.

\section{Weight Reduction (WR)}

Mengambil sampel data berat awal sebelum perendaman $\left(\mathrm{W}_{0 \mathrm{x}}\right)$ dan data berat sampel kering sebelum perendaman $\left(\mathrm{S}_{0 \mathrm{x}}\right)$. Kemudian sampel yang telah direndam, diambil dan ditiriskan. Kemudian, diletakkan pada cawan dan ditimbang untuk memperoleh data berat setelah perendaman $\left(\mathrm{W}_{\mathrm{x}}\right)$.

Keterangan:

$$
\mathrm{WRx}=\frac{\mathrm{W} 0 \mathrm{x}-\mathrm{Wx}}{\mathrm{S} 0 \mathrm{x}}
$$

WRx : Penurunan bobot sampel $x$.

W0x : Berat sampel $\mathrm{x}$ awal (g).

$\mathrm{Wx}$ : Berat sampel $\mathrm{x}$ setelah perendaman (g).

S0x : Berat kering sampel $\mathrm{x}$ sebelum perendaman $(\mathrm{g})$.

\section{Solid Gain (SG)}

Solid Gain (SG) dapat diperoleh, dengan menghitung solid fraction terlebih dahulu, dengan rumus dibawah:

SFX $=\frac{1}{3}\left(\frac{\text { Sx Ulangan } 1}{\text { W0x Ulangan } 1}+\frac{\text { Sx Ulangan } 2}{\text { W0x Ulangan } 2}+\right.$ $\left.\frac{\text { Sx Ulangan } 3}{\text { W0x Ulangan } 3}\right)$

Menghitung solid weight dengan rumus:

$$
\mathrm{SWx}=\mathrm{W}_{0 \mathrm{x}} \mathrm{x} \mathrm{SFx}
$$

Menghitung SG dengan rumus dibawah:

Keterangan:

$$
\mathrm{SGx}=\mathrm{W}_{0 \mathrm{x}}-\text { Solid weight }
$$

SGx : Solid gain pada sampel x (g).

SWx : Berat padatan (g).

SFx : Fraksi padatan.

Sx : Berat sampel $x$ kering $(\mathrm{g})$.

W0x : Berat sampel $x$ awal $(\mathrm{g})$.

\section{Water Loss (WL)}

Jumlah air yang keluar dari bahan dapat dihitung menggunakan data-data yang telah diolah yakni sebagai berikut: 
Keterangan:

$$
\mathrm{WL}_{\mathrm{x}}=\frac{\mathrm{W} 0 \mathrm{xF} 0-\mathrm{WxFx}}{\mathrm{Wx}}
$$

WLx : Jumlah air yang keluar dari bahan pada sampel x (g).

F0 : Fraksi air sampel awal.

Fx : Fraksi air sampel $\mathrm{x}$.

\section{Efektivitas Dehidrasi Osmosis}

Efektivits dehidrasi osmosis dapat diketahui dengan menjumlahkan air yang keluar dari bahan (WL) dengan padatan terlarut yang masuk dalam bahan (SG) dan dibagi dengan berat sampel kering sebelum perendaman $\left(S_{0}\right)$, dengan perhitungan sebagai berikut:

$$
\mathrm{Ex}=\frac{\mathrm{SGx}+\mathrm{WLx}}{\mathrm{S} 0}
$$

Keterangan:

Ex : Efektivitas proses dehidrasi osmosis sampel $\mathrm{x}$.

WLx : Air yang keluar dari sampel x (g).

SGx : Padatan terlarut yang masuk dalam sampel x (g).

S0 : Berat sampel kering awal (g).

\section{Metode Analisis}

Adapun metode analisis pada penelitian ini, yakni:

\section{Menentukan Model Matematis}

Salah satu metode untuk mengetahui hubungan antara dua variabel, melalui metode persamaan linear, seperti persamaan di bawah (Hijriani dkk., 2016):

Keterangan:

$$
\mathrm{Y}=\mathrm{a}+\mathrm{bX}
$$

Y : Variabel terikat.

A : Titik potong kurva terhadap sumbu Y (intercep).

B : Kemiringan (slope) kurva linear.

X : Variabel tidak terikat.

Model di atas merupakan analisis regresi yang mengamati hubungan antara variabel terikat $\mathrm{Y}$ dan variabel $\mathrm{X}$ yang tidak terikat. Selain itu, tujuan metode ini untuk memprediksi nilai $\mathrm{Y}$ untuk nilai $\mathrm{X}$ yang diberikan. a merupakan nilai $\mathrm{Y}$ yang pada saat $X=0$ dan $b$ merupakan perubahan ratarata nilai $Y$ terhadap perubahan satu unit $X$.

\section{Analisis Ragam}

Analisis ragam atau sidik ragam atau analisis variansi (ANOVA) adalah suatu cara untuk menguraikan ragam total menjadi komponen ragam. Contoh Tabel analisis ragam yang digunakan pada penelitian ini, diperlihatkan pada Tabel di bawah (Sastrosupadi, 2000):

Tabel 2. Contoh Tabel Analisis Ragam.

\begin{tabular}{ccccccc}
\hline SK & \multirow{2}{*}{ db } & \multirow{2}{*}{ KK } & K & $\begin{array}{c}\text { F } \\
\text { Hitung }\end{array}$ & $\mathbf{5 \%}$ & $\mathbf{1 \%}$ \\
\hline Perlakuan & & & & & \\
S & & & & & \\
K & & & & & \\
SK & & & & & \\
Galat & & & & & \\
Total & & & \\
Sumber: Sastrosupadi, 2000. & &
\end{tabular}

\section{Bagan Alir}

Bagan alir dalam penelitian ini, seperti yang diperlihatkan pada Gambar 1:

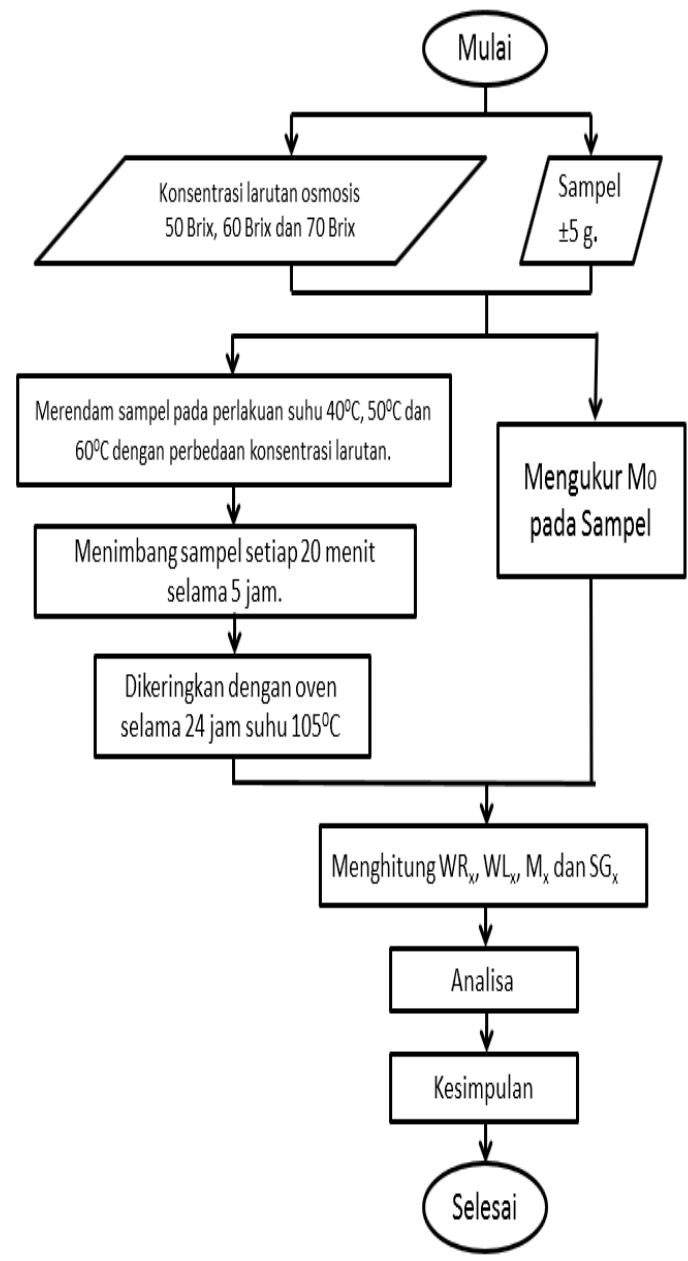

Gambar 1. Bagan Alir Penelitian.

\section{HASIL DAN PEMBAHASAN}

\section{Deskripsi Sampel}

Pisang kepok mengkal yang dibeli di Pasar Daya, Paccerakkang, Biringkanaya, Makassar, merupakan pisang kepok yang 
Jurnal AgriTechno. Vol. 11 (2): 98-112

https://doi.org/ 10.20956/at.v11i2.114

telah disimpan, sejak 2-3 hari setelah pemanenan. Pisang kepok dengan warna hijau kekuning-kuningan, dengan nilai kekerasan berdasarkan hasil uji yang dilakukan, sampai pada kedalaman $1.5 \mathrm{~cm}$ dan dilakukan sebanyak 2 kali pengulangan. Pada pengukuran pertama yakni sebesar $837.054 \mathrm{~N}$ dan pada pengukuran yang kedua yakni sebesar 700.536 N. Sehingga, rata-rata nilai yang diperoleh yakni sebesar 768.795 N. Dalam proses penelitian, pisang kepok mengkal dikupas kulitnya, dicuci dan dipotong pisang dengan berat masingmasing \pm 5 gram dengan tebal $\pm 0.5 \mathrm{~cm}$.

\section{Kadar Air}

\section{Analisis Ragam untuk Kadar Air}

Adapun Tabel analisis ragam untuk

kadar air, seperti pada Tabel di bawah:

Tabel 3. Analisis Ragam untuk kadar air.

\begin{tabular}{ccccccc}
\hline SK & $\mathbf{d}$ & JK & KT & $\begin{array}{c}\mathbf{F} \\
\text { Hitung }\end{array}$ & $\begin{array}{c}\mathbf{F} \\
\mathbf{5 \%}\end{array}$ & $\begin{array}{c}\mathbf{F} \\
\mathbf{1 \%}\end{array}$ \\
\hline Perla & 8 & 959. & 119. & 607.21 & 2.3 & 3.3 \\
kuan & & 9435 & 9929 & $41 * *$ & 600 & 600 \\
S & 2 & 228. & 114. & 578.36 & 3.4 & 4.7 \\
& & 5855 & 2928 & $89 * *$ & 000 & 200 \\
K & 2 & 551. & 275. & 1396.4 & 3.4 & 4.7 \\
& & 8971 & 9485 & $144 * *$ & 000 & 200 \\
SK & 4 & 179. & 44.8 & 227.03 & 2.7 & 4.2 \\
& & 4609 & 652 & $67 * *$ & 800 & 200 \\
Galat & 2 & 4.74 & 0.19 & & & \\
& 4 & 27 & 76 & & & \\
\cline { 6 - 7 } Total & 4 & 964. & & & & \\
& 2 & 6862 & & & &
\end{tabular}

Berdasarkan uji analisis ragam, pada Tabel 4 diketahui jika $F_{\text {hitung }}>\mathrm{F}_{1 \%}$. Maka, Ha diterima atau perlakuan (suhu dan konsentrasi larutan) yang diberikan secara individu memberikan pengaruh yang sangat nyata pada proses penurunan kadar air. Adapun interaksi antara perlakuan suhu dan konsentrasi larutan osmosis memberikan pengaruh sangat nyata pada penurunan kadar air. Hal ini sesuai dengan pendapat Sohibulloh dkk. (2013), bahwa suhu dan konsentrasi larutan memberikan pengaruh pada proses dehidrasi osmosis.

Tabel 4. Pengujian BNJ untuk Suhu terhadap kadar air.

\begin{tabular}{cccc}
\hline Perlakuan S & Total & $\begin{array}{c}\text { Rata-rata } \\
(\% \mathbf{B B})\end{array}$ & Notasi \\
\hline $40^{\circ} \mathrm{C}$ & 402.2327 & 44.6925 & $\mathrm{a}$ \\
\hline
\end{tabular}

\begin{tabular}{cccc}
\hline Perlakuan S & Total & $\begin{array}{c}\text { Rata-rata } \\
(\% \mathbf{B B})\end{array}$ & Notasi \\
\hline $50^{\circ} \mathrm{C}$ & 346.2883 & 38.4765 & $\mathrm{~b}$ \\
$60^{\circ} \mathrm{C}$ & 347.0838 & 38.5649 & $\mathrm{~b}$ \\
$\mathrm{BNJ} 5 \%$ & & 0.5228 & \\
\hline
\end{tabular}

Tabel 5 menunjukkan pengujian BNJ pada taraf $5 \%$ untuk suhu terhadap kadar air, diperoleh untuk suhu perendaman $40^{\circ} \mathrm{C}$ memiliki perbedaan dengan suhu perendaman $50^{\circ} \mathrm{C}$ dan $60^{\circ} \mathrm{C}$, pada kadar air yang dihasilkan.

Tabel 5. Pengujian BNJ untuk Konsentrasi terhadap kadar air.

\begin{tabular}{cccc}
\hline $\begin{array}{c}\text { Perlakuan } \\
\text { K }\end{array}$ & Total & $\begin{array}{c}\text { Rata-rata } \\
(\boldsymbol{\%} \mathbf{B B})\end{array}$ & Notasi \\
\hline 50 Brix & 413.8425 & 45.9825 & $\mathrm{a}$ \\
60 Brix & 367.5097 & 40.8344 & $\mathrm{~b}$ \\
70 Brix & 314.2525 & 34.9169 & $\mathrm{c}$ \\
BNJ 5\% & & 0.5228 & \\
\hline
\end{tabular}

Tabel 6 yang menunjukkan pengujian BNJ pada taraf 5\% untuk konsentrasi larutan gula, diketahui pada Tabel tersebut, setiap konsentrasi larutan gula memiliki perbedaan masing-masing, pada kadar air yang dihasilkan.

Tabel 7. Pengujian dengan BNJ untuk interaksi antara suhu dengan konsentrasi larutan gula terhadap kadar air

\begin{tabular}{|c|c|c|c|c|}
\hline \multicolumn{2}{|c|}{ Perlakuan } & \multirow{2}{*}{$\begin{array}{c}\text { Notasi } \\
\text { Perlakuan }\end{array}$} & \multirow{2}{*}{$\begin{array}{c}\text { Rata- } \\
\text { rata } \\
(\% \mathrm{BB})\end{array}$} & \multirow{2}{*}{$\begin{array}{l}\text { Lambang } \\
\text { Perlakuan }\end{array}$} \\
\hline Suhu & Konsentrasi & & & \\
\hline \multirow{3}{*}{$40^{\circ} \mathrm{C}$} & 50 Brix & $\mathrm{T} 1 \mathrm{~K} 1$ & 49.0925 & $\mathrm{a}$ \\
\hline & 60 Brix & $\mathrm{T} 1 \mathrm{~K} 2$ & 48.8969 & $\mathrm{a}$ \\
\hline & 70 Brix & T1K3 & 36.0882 & b \\
\hline \multirow{3}{*}{$50^{\circ} \mathrm{C}$} & 50 Brix & $\mathrm{T} 2 \mathrm{~K} 1$ & 41.7506 & $\mathrm{c}$ \\
\hline & 60 Brix & $\mathrm{T} 2 \mathrm{~K} 2$ & 38.6090 & d \\
\hline & 70 Brix & $\mathrm{T} 2 \mathrm{~K} 3$ & 35.0698 & b \\
\hline \multirow{4}{*}{$60^{\circ} \mathrm{C}$} & 50 Brix & T3K1 & 47.1044 & $\mathrm{e}$ \\
\hline & 60 Brix & T3K2 & 34.9973 & $\mathrm{~b}$ \\
\hline & 70 Brix & T3K3 & 33.5928 & $\mathrm{f}$ \\
\hline & BNJ 5\% & & 1.2338 & \\
\hline
\end{tabular}

Tabel 7 menunjukkan pengujian BNJ $5 \%$ untuk interaksi antara suhu dengan konsentrasi larutan gula terhadap kadar air, diperoleh pada perlakuan suhu $40^{\circ} \mathrm{C}$ dan konsentrasi 50 Brix memiliki perbedaan pada perlakuan suhu $40^{\circ} \mathrm{C}$ dan konsentrasi 70 Brix, suhu $50^{\circ} \mathrm{C}$ dan konsentrasi 50 Brix, suhu $50^{\circ} \mathrm{C}$ dan konsentrasi 60 Brix, suhu 
$50^{\circ} \mathrm{C}$ dan konsentrasi 70 Brix, suhu $60^{\circ} \mathrm{C}$ dan konsentrasi 50 Brix, suhu $60^{\circ} \mathrm{C}$ dan konsentrasi 60 Brix, dan suhu $60^{\circ} \mathrm{C}$ dan konsentrasi 70 Brix. Namun, memiliki pengaruh yang sama pada perlakuan suhu $40^{\circ} \mathrm{C}$ dan konsentrasi 60 Brix. Hal yang sama terdapat pada perlakuan suhu $40^{\circ} \mathrm{C}$ dan konsentrasi 70 Brix, yang memiliki pengaruh yang sama pada perlakuan suhu $50^{\circ} \mathrm{C}$ dan konsentrasi 70 Brix, dan suhu $60^{\circ} \mathrm{C}$ dan konsentrasi 60 Brix.

\section{Hubungan Pengaruh Kadar Air dengan Waktu}

Adapun hubungan pengaruh kadar air dengan waktu untuk suhu, yakni sebagai berikut:

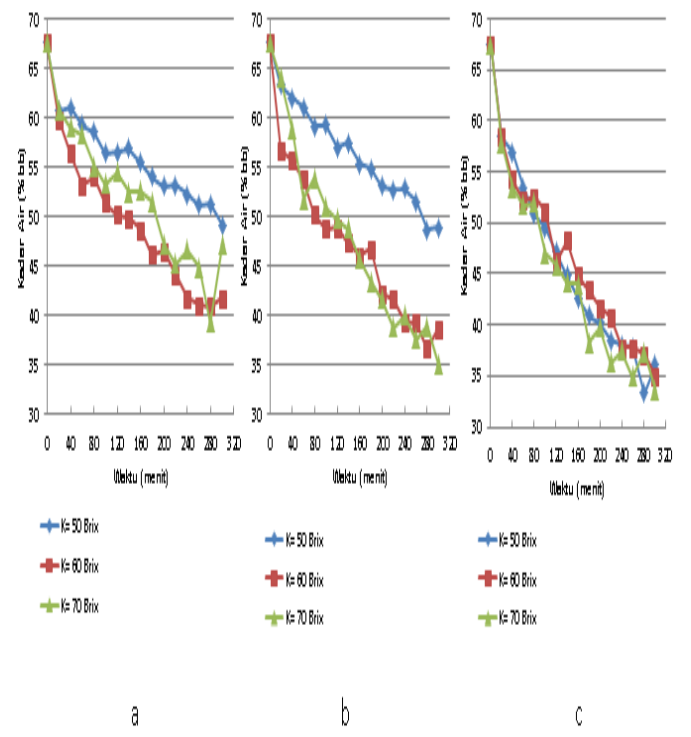

Gambar 2. Pengaruh suhu perendaman (a). $40^{\circ} \mathrm{C}$, (b). $50^{\circ} \mathrm{C}$ dan (c). $60^{\circ} \mathrm{C}$ terhadap penurunan kadar air basis basah pada konsentrasi larutan gula yang bervariasi.

Gambar 2 merupakan hubungan pengaruh antara kadar air dengan waktu, yang dipengaruhi oleh suhu pada konsentrasi larutan osmosis yang bervariasi. Pada Gambar 2 bagian c merupakan hubungan yang dipengaruhi oleh suhu $60^{\circ} \mathrm{C}$ (suhu yang tertinggi) yang memiliki penurunan kadar air yang paling tinggi, dengan kadar air sebesar $33.5928 \%$ basis basah. Hal tersebut diketahui jika semakin besar suhu perendaman yang diberikan. Maka, semakin besar penurunan kadar air yang terjadi. Hal tersebut sesuai dengan penelitian yang dilakukan Wirawan dan Anasta (2013), yang menyatakan jika suhu larutan osmosis berpengaruh dalam mengubah struktur dinding sel dan kerapatannya, sehingga mempengaruhi transfer massa maupun permeasi. Jika semakin tinggi suhu perendaman, maka struktur dinding sel dan kerapatannya akan semakin berkurang, sehingga mempercepat transfer massa dan permeasi pada proses osmosis. Pada Gambar 5 menunjukkan adanya bias pada data yang diperoleh, hal tersebut terjadi karena sampel yang digunakan selama pengukuran berbeda-beda.

Adapun hubungan pengaruh kadar air dengan waktu untuk konsentrasi larutan gula, yakni sebagai berikut:

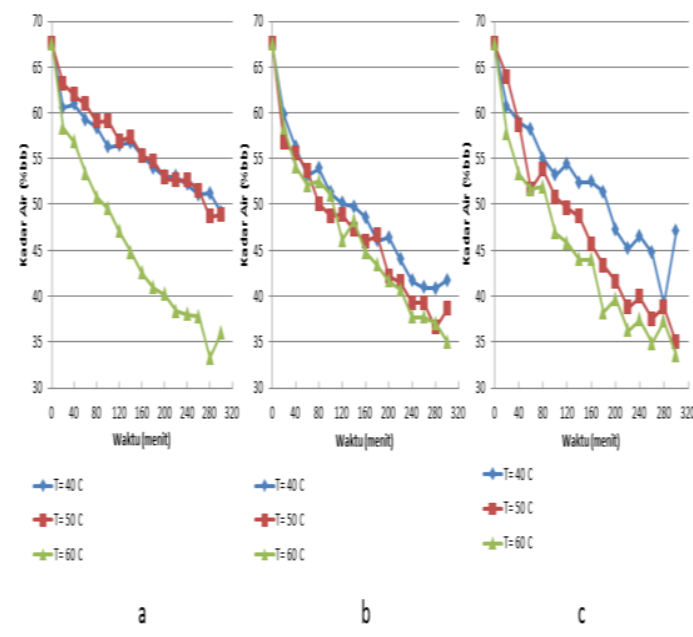

Gambar 3. Pengaruh konsentrasi larutan gula (a). 50 Brix, (b). 60 Brix dan (c). 70 Brix terhadap kadar air basis basah. pada suhu perendaman yang bervariasi.

Gambar 3 merupakan hubungan pengaruh antara kadar air dengan waktu, yang dipengaruhi oleh konsentrasi larutan gula pada suhu yang bervariasi. Pada Gambar tersebut terlihat, hubungan yang dipengaruhi oleh konsentrasi larutan gula 70 Brix (konsentrasi yang tertinggi), memiliki kadar air yang paling rendah, dengan kadar air sebesar $33.5928 \%$ basis basah. Hal tersebut diketahui jika semakin besar konsentrasi larutan osmosis yang diberikan. Maka, semakin besar penurunan kadar air yang terjadi. Hal ini sesuai dengan penelitian yang dilakukan Wirawan dan Anasta (2013), 
yang menyatakan bahwa konsentrasi larutan memberikan pengaruh beda potensial dalam sistem dehidrasi osmosis. Jika beda potensial semakin tinggi, maka semakin cepat air yang keluar dari dalam bahan makanan. Pada Gambar 3 juga menunjukkan adanya bias pada data yang diperoleh, hal tersebut terjadi karena sampel yang digunakan selama pengukuran berbedabeda.

Adapun hubungan pengaruh untuk interaksi antara suhu dengan konsentrasi larutan gula terhadap kadar air, yakni sebagai berikut:

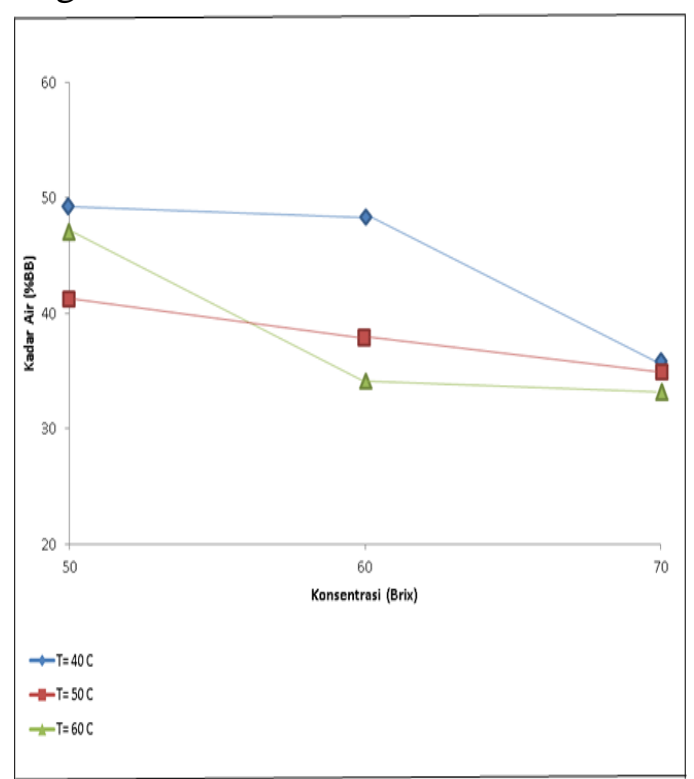

Gambar 4. Hubungan interaksi antara suhu dengan konsentrasi larutan gula terhadap kadar air.

Pada Gambar 4 merupakan hubungan pengaruh interaksi antara suhu dengan konsentrasi larutan gula terhadap kadar air. Pada Gambar tersebut, garis suhu $50^{\circ} \mathrm{C}$, saling-silang dengan garis suhu $60^{\circ} \mathrm{C}$. Hal tersebut menunjukkan adanya interaksi signifikan disordinal atau Ha diterima atau ada pengaruh antara suhu dengan konsentrasi dalam menghasilkan kadar air basis basah yang rendah. Hal ini sesuai dengan pendapat Wirawan dan Anasta (2013), yang menyatakan bahwa semakin tinggi suhu dan konsentrasi larutan osmosis, air yang berpindah ke larutan osmosis semakin banyak.
Weight Reduction (WR)

\section{Analisis Ragam untuk Weight Reduction (WR)}

Adapun Tabel analisis ragam untuk WR, seperti pada Tabel di bawah:

Tabel 5. Analisis ragam Weight Reduction (WR).

\begin{tabular}{ccccccc}
\hline SK & $\mathbf{d}$ & JK & KT & $\begin{array}{c}\mathbf{F} \\
\text { Hitung }\end{array}$ & $\begin{array}{c}\mathbf{F} \\
\mathbf{5 \%}\end{array}$ & $\begin{array}{c}\mathbf{F} \\
\mathbf{1 \%}\end{array}$ \\
\hline berla & 8 & 0.7 & 0.0 & 597.83 & 2.3 & 3.3 \\
kuan & & 642 & 955 & $30^{* *}$ & 600 & 600 \\
S & 2 & 0.4 & 0.2 & 1310.8 & 3.4 & 4.7 \\
& & 189 & 095 & $807^{* *}$ & 000 & 200 \\
K & 2 & 0.2 & 0.1 & 918.05 & 3.4 & 4.7 \\
& & 934 & 467 & $25^{* *}$ & 000 & 200 \\
SK & 4 & 0.0 & 0.0 & 81.199 & 2.7 & 4.2 \\
& & 519 & 130 & $4 * *$ & 800 & 200 \\
Galat & 2 & 0.0 & 0.0 & & & \\
& 4 & 038 & 002 & & & \\
Total & 4 & 0.7 & & & & \\
& 2 & 681 & & & &
\end{tabular}

Berdasarkan uji analisis ragam, pada Tabel 5 diketahui jika $F_{h i t u n g}>F_{1 \%}$. Maka, Ha diterima atau perlakuan (suhu dan konsentrasi larutan) yang diberikan secara individu memberikan pengaruh yang sangat nyata pada WR. Adapun interaksi antara perlakuan suhu dan konsentrasi larutan osmosis memberikan pengaruh sangat nyata terhadap Weight Reduction (WR). Hal ini sesuai dengan pendapat Sankat et al. (2006), dalam Witono dkk. (2013), yang menyatakan bahwa proses dehidrasi osmosis memberikan pengaruh pada WR.

Tabel 6. BNJ untuk suhu terhadap WR.

\begin{tabular}{cccc}
\hline Perlakuan S & Total & Rata-rata & Notasi \\
\hline $40^{\circ} \mathrm{C}$ & 6.8744 & 0.7638 & $\mathrm{a}$ \\
$50^{\circ} \mathrm{C}$ & 7.7225 & 0.8581 & $\mathrm{~b}$ \\
$60^{\circ} \mathrm{C}$ & 9.5604 & 1.0623 & $\mathrm{c}$ \\
$\mathrm{BNJ} 5 \%$ & & 0.0166 & \\
\hline
\end{tabular}

Tabel 6 menunjukkan pengujian BNJ pada taraf 5\% untuk suhu terhadap WR, diperoleh setiap perlakuan suhu mempunyai perbedaan masing-masing terhadap Weight Reduction (WR) yang dihasilkan. 
Tabel 7. BNJ untuk Konsentrasi Larutan Gula terhadap WR

\begin{tabular}{|c|c|c|c|}
\hline Perlakuan K & Total & Rata-rata & Notasi \\
\hline 50 Brix & 6.7866 & 0.7540 & $\mathrm{a}$ \\
\hline 60 Brix & 8.3407 & 0.9267 & $\mathrm{~b}$ \\
\hline 70 Brix & 9.0298 & 1.0033 & $\mathrm{c}$ \\
\hline BNJ 5\% & \multicolumn{3}{|c}{0.0166} \\
\hline
\end{tabular}

Tabel 7 menunjukkan pengujian BNJ pada taraf 5\% untuk konsentrasi larutan gula, diketahui pada Tabel tersebut, setiap konsentrasi larutan memiliki perbedaan masing-masing terhadap Weight Reduction (WR) yang dihasilkan.

Tabel 8. Pengujian dengan BNJ untuk Interaksi antara Suhu dengan Konsentrasi larutan gula terhadap WR

\begin{tabular}{|c|c|c|c|c|}
\hline \multicolumn{2}{|c|}{ Perlakuan } & \multirow{2}{*}{$\begin{array}{c}\text { Notasi } \\
\text { Perlak } \\
\text { uan }\end{array}$} & \multirow[b]{2}{*}{$\begin{array}{l}\text { Rata- } \\
\text { rata }\end{array}$} & \multirow{2}{*}{$\begin{array}{c}\text { Lamba } \\
\text { ng } \\
\text { Perlak } \\
\text { uan } \\
\end{array}$} \\
\hline $\begin{array}{l}\text { Su } \\
\text { hu }\end{array}$ & $\begin{array}{c}\text { Konsent } \\
\text { rasi }\end{array}$ & & & \\
\hline \multirow{3}{*}{$\begin{array}{c}40^{\circ} \\
\mathrm{C}\end{array}$} & 50 Brix & T1K1 & 0.6358 & $\mathrm{a}$ \\
\hline & 60 Brix & T1K2 & 0.7645 & $\mathrm{~b}$ \\
\hline & 70 Brix & T1K3 & 0.8911 & $\mathrm{c}$ \\
\hline \multirow{3}{*}{$\begin{array}{c}50^{\circ} \\
\mathrm{C}\end{array}$} & 50 Brix & $\mathrm{T} 2 \mathrm{~K} 1$ & 0.7819 & $\mathrm{~b}$ \\
\hline & 60 Brix & $\mathrm{T} 2 \mathrm{~K} 2$ & 0.8681 & $\mathrm{~d}$ \\
\hline & 70 Brix & $\mathrm{T} 2 \mathrm{~K} 3$ & 0.9242 & $\mathrm{e}$ \\
\hline \multirow{3}{*}{$\begin{array}{c}60^{\circ} \\
\mathrm{C}\end{array}$} & 50 Brix & T3K1 & 0.8445 & $\mathrm{f}$ \\
\hline & 60 Brix & T3K2 & 1.1476 & $\mathrm{~g}$ \\
\hline & 70 Brix & T3K3 & 1.1947 & $\mathrm{~h}$ \\
\hline \multicolumn{3}{|c|}{ BNJ 5\% } & 0.0202 & \\
\hline
\end{tabular}

Tabel 8 menunjukkan pengujian BNJ $5 \%$ untuk interaksi antara suhu dengan konsentrasi larutan gula terhadap Weight Reduction (WR), diperoleh pada perlakuan suhu $40^{\circ} \mathrm{C}$ dan konsentrasi 50 Brix memiliki perbedaan denan perlakuan suhu $40^{\circ} \mathrm{C}$ dan konsentrasi 60 Brix, suhu $40^{\circ} \mathrm{C}$ dan konsentrasi 70 Brix, suhu $50^{\circ} \mathrm{C}$ dan konsentrasi 50 Brix, suhu $50^{\circ} \mathrm{C}$ dan konsentrasi 60 Brix, suhu $50^{\circ} \mathrm{C}$ dan konsentrasi 70 Brix, suhu $60^{\circ} \mathrm{C}$ dan konsentrasi 50 Brix, suhu $60^{\circ} \mathrm{C}$ dan konsentrasi 60 Brix dan suhu $60^{\circ} \mathrm{C}$ dan konsentrasi 70 Brix. Namun, pada perlakuan suhu $40^{\circ} \mathrm{C}$ dan konsentrasi 60 Brix mempunyai kesamaan dengan perlakuan suhu $50^{\circ} \mathrm{C}$ dan konsentrasi 50 Brix.
Jurnal AgriTechno. Vol. 11 (2): 98-112

https://doi.org/ 10.20956/at.v11i2.114

\section{Hubungan Pengaruh Weight Reduction (WR) dengan Waktu}

Adapun hubungan pengaruh Weight Reduction (WR) dengan waktu untuk suhu, yakni sebagai berikut:

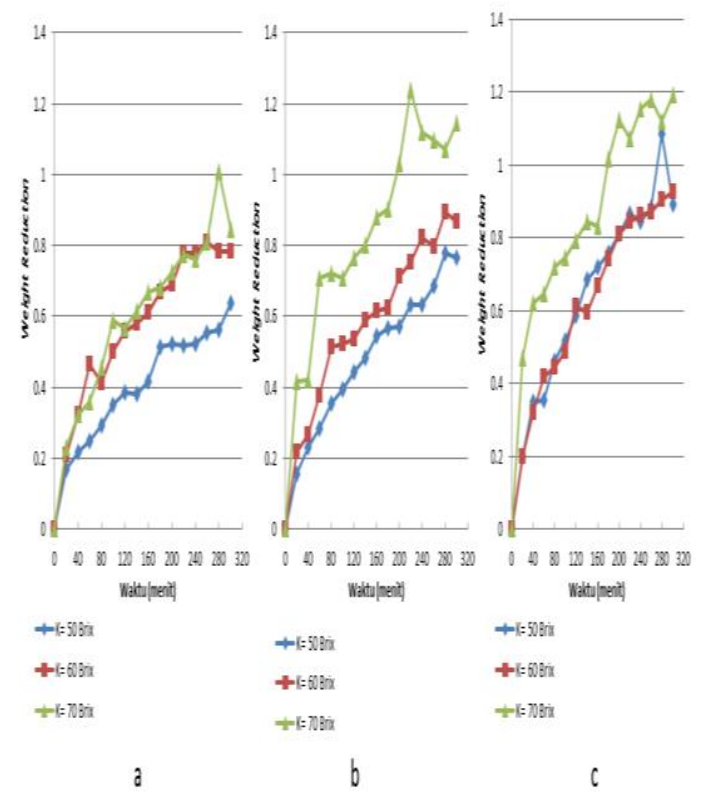

Gambar 5. Pengaruh suhu perendaman (a). $40^{\circ} \mathrm{C}$, (b). $50^{\circ} \mathrm{C}$ dan (c). $60^{\circ} \mathrm{C}$ terhadap peningkatan Weight Reduction (WR) pada konsentrasi larutan gula yang bervariasi.

Pada Gambar 5 merupakan hubungan pengaruh antara WR dengan waktu, yang dipengaruhi oleh suhu pada konsentrasi larutan osmosis yang bervariasi. Hubungan yang dipengaruhi oleh suhu $60^{\circ} \mathrm{C}$ (suhu yang tertinggi) memberikan penurunan bobot (WR) yang paling tinggi, dengan penurunan bobot (WR) sebesar 1.1947. Hal tersebut diketahui, jika semakin besar suhu perendaman yang diberikan. Maka, semakin besar penurunan bobot (WR) yang terjadi. Hal tersebut sesuai dengan penelitian yang dilakukan Wirawan dan Anasta (2013), yang menyatakan jika suhu larutan osmosis berpengaruh dalam mengubah struktur dinding sel dan kerapatannya, sehingga mempengaruhi transfer massa maupun permeasi. Jika semakin tinggi suhu perendaman, maka struktur dinding sel dan kerapatannya akan semakin berkurang, sehingga mempercepat transfer massa dan permeasi pada proses osmosis. Pada Gambar 
8 juga menunjukkan adanya bias pada data yang diperoleh, hal tersebut terjadi karena sampel yang digunakan selama pengukuran berbeda-beda.

Adapun hubungan pengaruh Weight Reduction (WR) dengan waktu untuk konsentrasi larutan, yakni sebagai berikut:

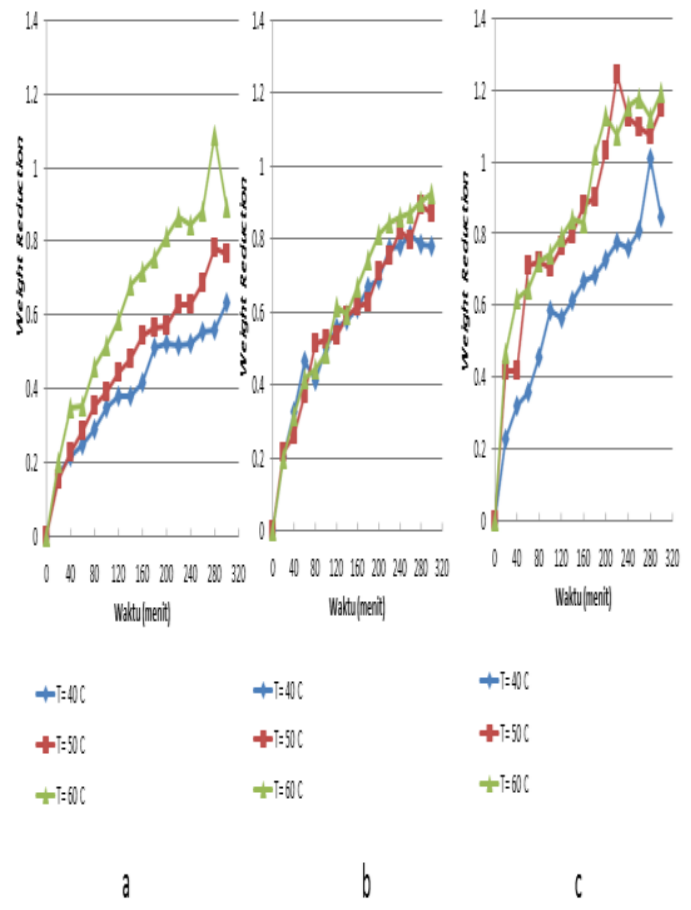

Gambar 6. Pengaruh konsentrasi larutan gula (a). 50 Brix, (b). 60 Brix, dan (c). 70 Brix terhadap peningkatan Weight Reduction (WR) pada suhu perendaman yang bervariasi.

Gambar 6 merupakan hubungan pengaruh antara Weight Reduction (WR) dengan waktu, yang dipengaruhi oleh konsentrasi larutan gula pada suhu yang bervariasi. Pada Gambar 9 merupakan hubungan yang dipengaruhi oleh suhu $60^{\circ} \mathrm{C}$ (suhu yang tertinggi) dan konsentrasi 70 Brix (konsentrasi yang tertinggi), yang memiliki penurunan bobot (WR) yang paling tinggi, dengan penurunan bobot (WR) sebesar 1.1947. Hal tersebut terjadi karena adanya beda potensial yang tinggi pada 2 jenis konsentrasi larutan, yakni larutan di dalam bahan makanan yang rendah dan larutan di luar bahan makanan yang tinggi. Hal ini sesuai dengan penelitian yang dilakukan Wirawan dan Anasta (2013), yang menyatakan bahwa konsentrasi larutan memberikan pengaruh beda potensial dalam sistem dehidrasi osmosis. Jika beda potensial semakin tinggi, maka semakin cepat air yang keluar dari dalam bahan makanan. Pada Gambar 6 juga menunjukkan adanya bias pada data yang diperoleh, hal tersebut terjadi karena sampel yang digunakan selama pengukuran berbedabeda.

Adapun hubungan pengaruh antara interaksi suhu dengan konsentrasi larutan gula terhadap WR, yakni sebagai berikut:

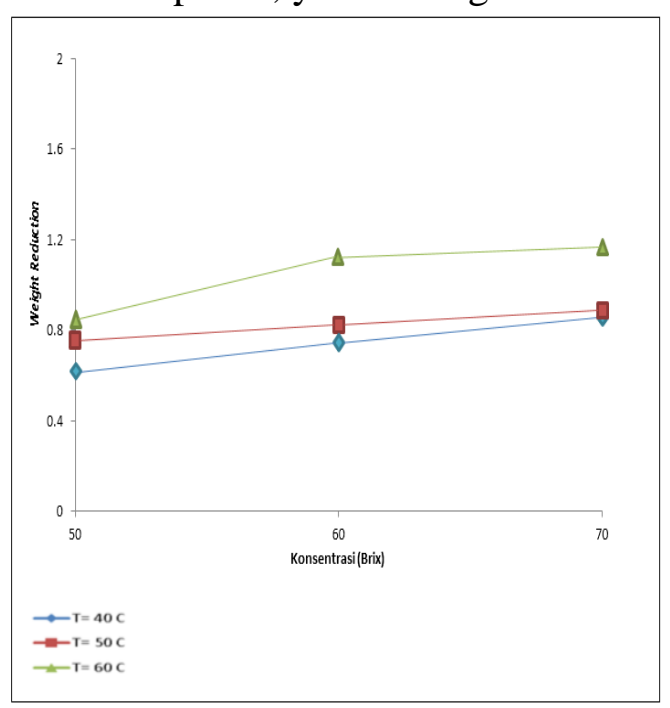

Gambar 7. Hubungan pengaruh interaksi suhu dengan konsentrasi larutan gula terhadap WR.

Pada Gambar 7 merupakan hubungan pengaruh interaksi antara suhu dengan konsentrasi larutan gula terhadap WR. Pada gambar tersebut, garis suhu $40^{\circ} \mathrm{C}$ segaris dengan garis suhu $50^{\circ} \mathrm{C}$. Hal tersebut menunjukkan adanya interaksi signifikan ordinal atau Ha diterima atau ada pengaruh antara Suhu dengan Konsentrasi dalam menghasilkan WR yang tinggi. Hal ini sesuai dengan pendapat Wirawan (2013), yang menyatakan bahwa semakin tinggi suhu dan konsentrasi larutan osmosis, air yang berpindah ke larutan osmosis semakin banyak.

\section{Solid Gain (SG)}

Analisis Ragam untuk Solid Gain (SG)

Adapun Tabel analisis ragam untuk Solid Gain (SG), seperti pada Tabel di bawah: 
Tabel 8. Analisis ragam untuk Solid Gain (SG).

\begin{tabular}{|c|c|c|c|c|c|c|}
\hline SK & $\begin{array}{l}\text { d } \\
\text { b }\end{array}$ & JK & KT & $\begin{array}{c}\mathbf{F} \\
\text { Hitun } \\
\mathbf{g}\end{array}$ & $\underset{\mathbf{5 \%}}{\mathbf{F}}$ & $\begin{array}{c}F \\
1 \%\end{array}$ \\
\hline $\begin{array}{c}\text { Perlak } \\
\text { uan }\end{array}$ & 8 & $\begin{array}{c}0.26 \\
91\end{array}$ & $\begin{array}{c}0.03 \\
36\end{array}$ & $\begin{array}{c}3.4050 \\
* *\end{array}$ & $\begin{array}{c}2.36 \\
00\end{array}$ & $\begin{array}{c}3.36 \\
00\end{array}$ \\
\hline$S$ & 2 & $\begin{array}{c}0.27 \\
67\end{array}$ & $\begin{array}{c}0.13 \\
83\end{array}$ & $\begin{array}{c}14.004 \\
3^{* *}\end{array}$ & $\begin{array}{c}3.40 \\
00\end{array}$ & $\begin{array}{c}4.72 \\
00\end{array}$ \\
\hline K & 2 & $\begin{array}{c}0.15 \\
07\end{array}$ & $\begin{array}{c}0.07 \\
53\end{array}$ & $\begin{array}{c}7.6263 \\
* *\end{array}$ & $\begin{array}{c}3.40 \\
00\end{array}$ & $\begin{array}{c}4.72 \\
00\end{array}$ \\
\hline SK & 4 & $\begin{array}{c}0.07 \\
43\end{array}$ & $\begin{array}{c}0.01 \\
86\end{array}$ & $\underset{\mathrm{tn}}{1.8809}$ & $\begin{array}{c}2.78 \\
00\end{array}$ & $\begin{array}{c}4.22 \\
00\end{array}$ \\
\hline Galat & $\begin{array}{l}2 \\
4\end{array}$ & $\begin{array}{c}0.23 \\
71\end{array}$ & $\begin{array}{c}0.00 \\
99\end{array}$ & & & \\
\hline Total & $\begin{array}{l}4 \\
2\end{array}$ & $\begin{array}{c}0.50 \\
61\end{array}$ & & & & \\
\hline
\end{tabular}

Berdasarkan uji analisis ragam pada Tabel 8 diketahui jika pada baris perlakuan suhu perendaman dan perlakuan konsentrasi larutan gula secara individu, memiliki $F_{\text {hitung }}$ $>\mathrm{F}_{1 \%}$ atau Ha diterima pada taraf $1 \%$, artinya pemberian perlakuan suhu perendaman dan perlakuan konsentrasi larutan gula secara individu, memberikan pengaruh yang sangat nyata terhadap Solid Gain (SG). Sedangkan, pada baris interaksi suhu dengan konsentrasi larutan, memiliki $\mathrm{F}_{\text {hitung }}<\mathrm{F}_{5 \%}$ atau $\mathrm{H}_{0}$ diterima, artinya tidak ada pengaruh antara suhu dengan konsentrasi larutan terhadap Solid Gain (SG). Hal ini sesuai dengan pendapat Sharma et al. (2000), yang menyatakan bahwa perlakuan suhu dan perlakuan konsentrasi larutan secara individu memberikan pengaruh pada nilai solid gain.

Tabel 9. BNJ untuk suhu terhadap SG.

\begin{tabular}{cccc}
\hline Perlakuan S & Total & Rata-rata $(\mathbf{g})$ & Notasi \\
\hline $40^{\circ} \mathrm{C}$ & 27.0752 & 3.0084 & $\mathrm{a}$ \\
$50^{\circ} \mathrm{C}$ & 27.0678 & 3.0075 & $\mathrm{a}$ \\
$60^{\circ} \mathrm{C}$ & 25.1389 & 2.7932 & $\mathrm{~b}$ \\
$\mathrm{BNJ} 5 \%$ & & 0.0130 & \\
\hline
\end{tabular}

Tabel 9 menunjukkan pengujian BNJ pada taraf 5\% untuk suhu terhadap solid gain. Diketahui pada Tabel diatas, bahwa pada perlakuan suhu $40^{\circ} \mathrm{C}$ memiliki kesamaan dengan perlakuan suhu $50^{\circ} \mathrm{C}$ terhadap solid gain yang dihasilkan. Namun, pada perlakuan tersebut berbeda dengan perlakuan suhu $60^{\circ} \mathrm{C}$ terhadap solid gain yang dihasilkan.
Tabel 10. BNJ untuk konsentrasi larutan gula terhadap SG.

\begin{tabular}{cccc}
$\begin{array}{c}\text { Perlakuan } \\
\text { K }\end{array}$ & Total & $\begin{array}{c}\text { Rata-rata } \\
(\mathbf{g})\end{array}$ & Notasi \\
\hline 50 Brix & 26.8672 & 2.9852 & $\mathrm{a}$ \\
60 Brix & 25.4774 & 2.8308 & $\mathrm{~b}$ \\
70 Brix & 26.9373 & 2.9930 & $\mathrm{c}$ \\
BNJ 5\% & & 0.0130 & \\
\hline
\end{tabular}

Tabel 10 menunjukkan pengujian BNJ pada taraf 5\% untuk konsentrasi larutan terhadap solid gain. Diketahui pada Tabel diatas, bahwa setiap perlakuan konsentrasi larutan memiliki perbedaan terhadap solid gain yang dihasilkan.

\section{Hubungan Pengaruh Solid Gain (SG) dengan Waktu}

Adapun hubungan pengaruh SG dengan waktu untuk suhu, yakni:

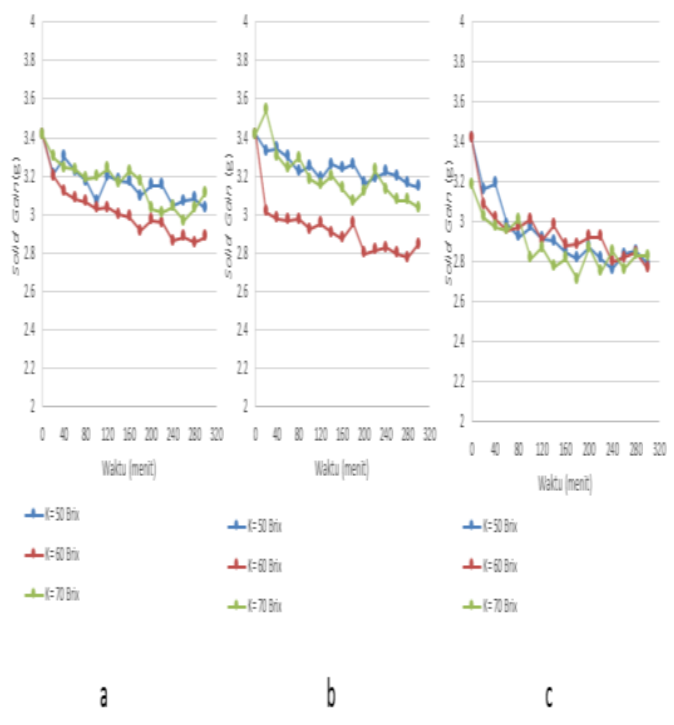

Gambar 8. Pengaruh suhu perendaman (a). $40^{\circ} \mathrm{C}$, (b). $50^{\circ} \mathrm{C}$, dan (c). $60^{\circ} \mathrm{C}$ terhadap $\mathrm{SG}$ pada konsentrasi larutan gula yang bervariasi.

Pada Gambar 8 merupakan hubungan pengaruh antara SG dengan waktu, yang dipengaruhi oleh suhu pada konsentrasi larutan osmosis yang bervariasi. Pada gambar tersebut pada bagian c merupakan hubungan pengaruh dengan suhu perendaman yang tertinggi atau suhu $60^{\circ} \mathrm{C}$ merupakan suhu yang menghasilkan solid gain yang terendah. Hal ini sesuai dengan pendapat Sharma et al. (2000), yang 
menyatakan suhu yang tertinggi merupakan suhu yang paling baik dalam menurunkan nilai solid gain pada bahan makanan. Hal terjadi karena suhu larutan osmosis berpengaruh dalam mengubah struktur dinding sel dan kerapatannya, sehingga mempengaruhi transfer massa maupun permeasi. Jika semakin tinggi suhu perendaman, maka struktur dinding sel dan kerapatannya akan semakin berkurang, sehingga mempercepat transfer massa dan permeasi pada proses osmosis (Wirawan dan Anasta, 2013). Pada Gambar 11 juga menunjukkan adanya bias pada data yang diperoleh, hal tersebut terjadi karena sampel yang digunakan selama pengukuran berbeda-beda.

Adapun hubungan pengaruh Solid Gain (SG) dengan waktu untuk konsentrasi larutan, yakni sebagai berikut:

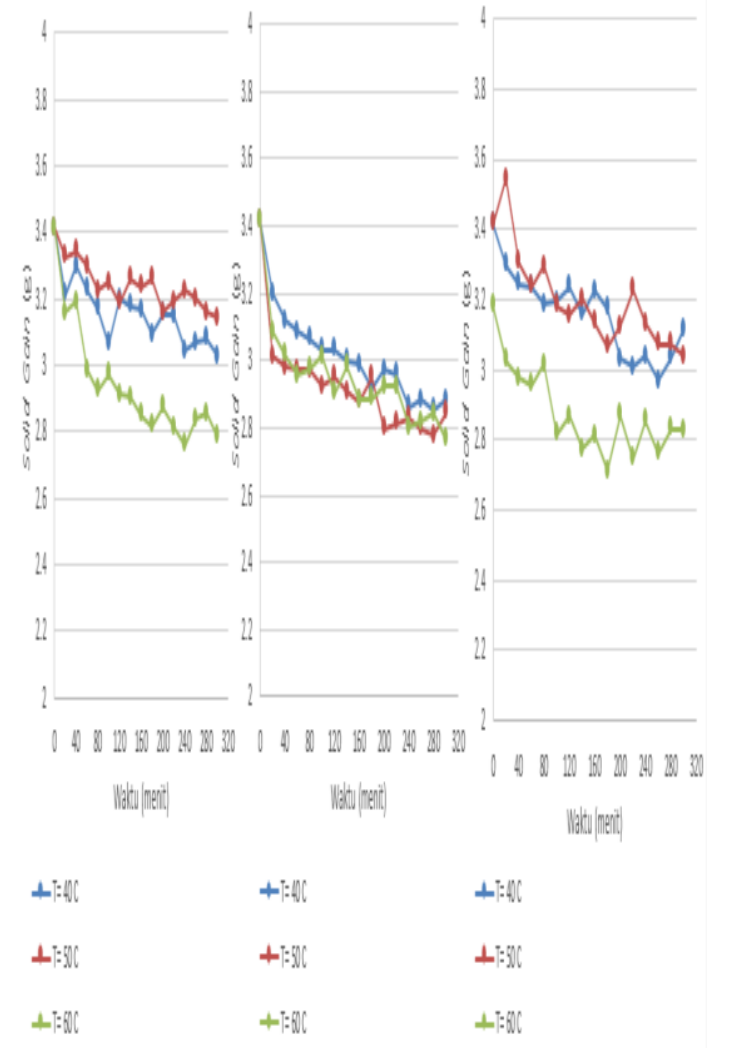

(a) (b) (c)

Gambar 9. Pengaruh konsentrasi larutan gula (a). 50 Brix, (b). 60 Brix, dan (c). 70 Brix terhadap peningkatan Solid Gain (SG) pada suhu perendaman yang bervariasi.

Gambar 9 merupakan hubungan pengaruh antara SG dengan waktu, yang dipengaruhi oleh konsentrasi larutan gula pada suhu yang bervariasi. Pada Gambar 9 pada bagian $b$ atau pada konsentrasi 60 Brix, memberikan solid gain akhir yang terendah. Hal tersebut sesuai dengan pendapat Magdalena dkk. (2013), dalam penelitiannya yang menyatakan bahwa konsentrasi 60 Brix merupakan konsentrasi larutan glukosa yang paling baik yang digunakan dalam nilai Solid Gain (SG) yang rendah. Pada Gambar 12 juga menunjukkan adanya bias pada data yang diperoleh, hal tersebut terjadi karena sampel yang digunakan selama pengukuran berbeda-beda.

\section{Water Loss (WL)}

\section{Analisis Ragam untuk Water Loss (WL)}

Adapun Tabel hasil analisis ragam untuk Water Loss (WL), seperti pada Tabel di bawah:

Tabel 11. Analisis ragam untuk Water Loss (WL).

\begin{tabular}{ccccccc}
\hline SK & db & \multirow{2}{*}{ JK } & \multirow{2}{*}{ KT } & $\begin{array}{c}\mathbf{F} \\
\text { Hitung }\end{array}$ & $\begin{array}{c}\mathbf{F} \\
\mathbf{5 \%}\end{array}$ & $\begin{array}{c}\mathbf{F} \\
\mathbf{1 \%}\end{array}$ \\
\cline { 1 - 5 } Perlakuan & 8 & 1.92 & 0.24 & $1.4989^{\text {th }}$ & 2.36 & 3.36 \\
S & 2 & 0.43 & 0.21 & $1.3670^{\text {tn }}$ & 3.40 & 4.72 \\
K & 2 & 1.13 & 0.56 & $3.5374^{*}$ & 3.40 & 4.72 \\
SK & 4 & 0.35 & 0.08 & $0.5455^{\text {th }}$ & 2.78 & 4.22 \\
Galat & 24 & 3.85 & 0.16 & & & \\
Total & 42 & 1.93 & & & & \\
\cline { 1 - 2 }
\end{tabular}

Berdasarkan uji analisis ragam pada Tabel 11 diketahui, pada baris perlakuan suhu perendaman secara individu dan interaksi antara suhu dengan konsentrasi larutan gula, memiliki $\mathrm{F}_{\text {hitung }}<\mathrm{F}_{5} \%$ atau $\mathrm{H}_{0}$ diterima, artinya pemberian perlakuan suhu perendaman secara individu dan perlakuan interaksi antara suhu dengan konsentrasi larutan gula, tidak memberikan pengaruh terhadap Water Loss (WL). Sedangkan, pada baris perlakuan konsentrasi larutan gula secara individu, memiliki $F_{\text {hitung }}>\mathrm{F}_{5 \%}$ atau Ha diterima, artinya perlakuan konsentrasi larutan gula secara individu memberikan pengaruh terhadap Water Loss (WL). Hal ini sesuai dengan pendapat Wirawan dan Anasta (2013), yang menyatakan bahwa konsentrasi larutan osmosis berpengaruh dalam beda potensial larutan di dalam sel dan di luar sel. Jika beda potensial yang terjadi pada 2 jenis larutan semakin tinggi, 
maka air yang keluar dari dalam sel semakin besar.

Tabel 12. BNJ untuk konsentrasi larutan gula terhadap WL.

\begin{tabular}{cccc}
$\begin{array}{c}\text { Perlakuan } \\
\text { K }\end{array}$ & Total & Rata-rata & Notasi \\
\hline 50 Brix & 7.4786 & 0.8310 & $\mathrm{a}$ \\
60 Brix & 6.1034 & 0.6782 & $\mathrm{a}$ \\
70 Brix & 10.5234 & 1.1693 & $\mathrm{~b}$ \\
BNJ 5\% & & 0.4716 & \\
\hline
\end{tabular}

Tabel 16 menunjukkan pengujian BNJ pada taraf $5 \%$ untuk konsentrasi larutan gula terhadap water loss. Diketahui pada Tabel diatas, pada perlakuan konsentrasi larutan gula 50 Brix memiliki kesamaan dengan perlakuan konsentrasi larutan gula 60 Brix, dalam menghasilkan water loss. Namun, perlakuan tersebut memiliki perbedaan dengan konsentrasi larutan gula 70 Brix terhadap water loss yang dihasilkan.

\section{Hubungan Pengaruh Water Loss (WL) dengan Waktu}

Adapun hubungan pengaruh WL dengan waktu untuk suhu, yakni:

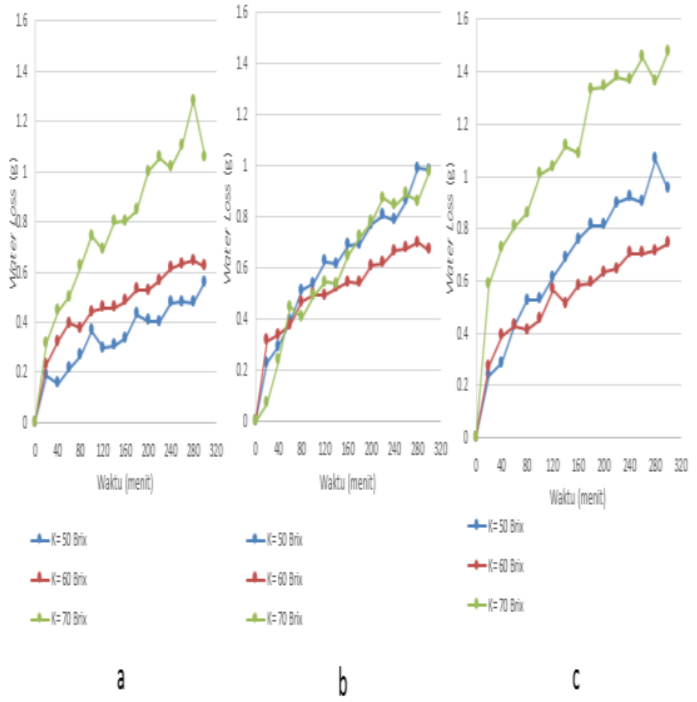

Gambar 10. Pengaruh suhu perendaman (a). $40^{\circ} \mathrm{C}$, (b). $50^{\circ} \mathrm{C}$ dan (c). $60^{\circ} \mathrm{C}$ terhadap peningkatan padatan terlarut (WL) pada konsentrasi larutan gula yang bervariasi.

Pada Gambar 10 merupakan hubungan pengaruh antara water loss dengan waktu, yang dipengaruhi oleh suhu pada konsentrasi larutan osmosis yang bervariasi. Dari Gambar tersebut dapat diketahui, pada bagian c atau pada suhu $60^{\circ} \mathrm{C}$ memiliki peningkatan water loss yang tertinggi. Hal ini sesuai dengan pendapat Magdalena dkk. (2014), melalui penelitiannya, tentang pengaruh suhu dan konsentrasi larutan gula terhadap proses dehidrasi osmosis buah waluh. Suhu yang paling baik dalam penelitian tersebut diberikan pada suhu tertinggi, karena menghasilkan water loss yang paling tinggi. Pada Gambar 10 juga menunjukkan adanya bias pada data yang diperoleh, hal tersebut terjadi karena sampel yang digunakan selama pengukuran berbeda-beda.

Adapun hubungan pengaruh Water Loss (WL) untuk konsentrasi larutan, yakni sebagai berikut:

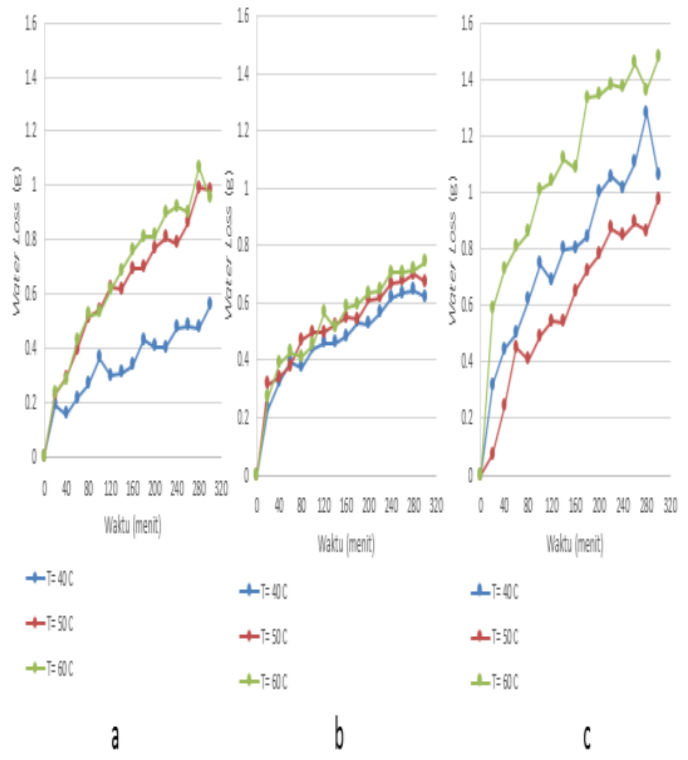

Gambar 11. Pengaruh konsentrasi larutan osmosis (a). 50 Brix, (b). 60 Brix dan (c). 70 Brix terhadap peningkatan water loss (WL) pada suhu perendaman yang bervariasi.

Gambar 11 merupakan hubungan pengaruh antara WL dengan waktu, yang dipengaruhi oleh konsentrasi larutan gula pada suhu yang bervariasi. Dari Gambar 11 pada bagian c atau pada konsentrasi larutan gula 70 Brix merupakan grafik yang memiliki peningkatan WL tertinggi. Hal ini juga sesuai dengan pendapat Magdalena dkk. (2014), yang menyatakan bahwa meningkatnya nilai water loss (WL) disebabkan karena perbedaan tekanan osmosis yang lebih besar antara larutan gula 
dengan air dalam bahan. Perbedaan tekanan tersebut menjadi driving force yang menyebabkan massa air pada bahan mengalir keluar dari bahan menuju media larutan. Pada Gambar 11 juga menunjukkan adanya bias pada data yang diperoleh, hal tersebut terjadi karena sampel yang digunakan selama pengukuran berbedabeda.

\section{Efektivitas Dehidrasi Osmosis}

Adapun efektivitas poses dehidrasi osmosis, dapat dilihat pada hubungan pengaruh efektivitas dengan waktu, di bawah:

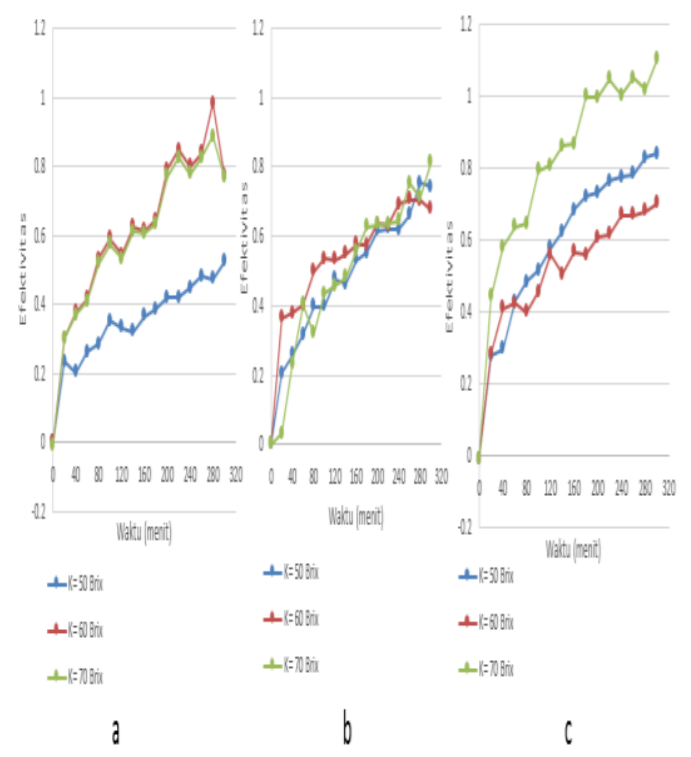

Gambar 12. Pengaruh suhu perendaman (a). $40^{\circ} \mathrm{C}$, (b). $50^{\circ} \mathrm{C}$ dan (c). $60^{\circ} \mathrm{C}$ terhadap efektivitas pada konsentrasi larutan gula yang bervariasi.

Pada Gambar 12 merupakan hubungan pengaruh antara efektivitas dengan waktu, yang dipengaruhi oleh suhu pada konsentrasi larutan osmosis yang bervariasi. Hubungan yang dipengaruhi oleh suhu $60^{\circ} \mathrm{C}$ memberikan efektivitas yang paling tinggi. Hal ini sesuai dengan pendapat Magdalena dkk. (2014), melalui penelitiannya, tentang pengaruh suhu dan konsentrasi larutan gula terhadap proses dehidrasi osmosis buah waluh. Suhu yang paling baik dalam penelitian tersebut diberikan pada suhu tertinggi, karena menghasilkan penghilangan air yang paling tinggi. Gambar
12 juga menunjukkan adanya bias pada data yang diperoleh, hal tersebut terjadi karena sampel yang digunakan selama pengukuran berbeda-beda.

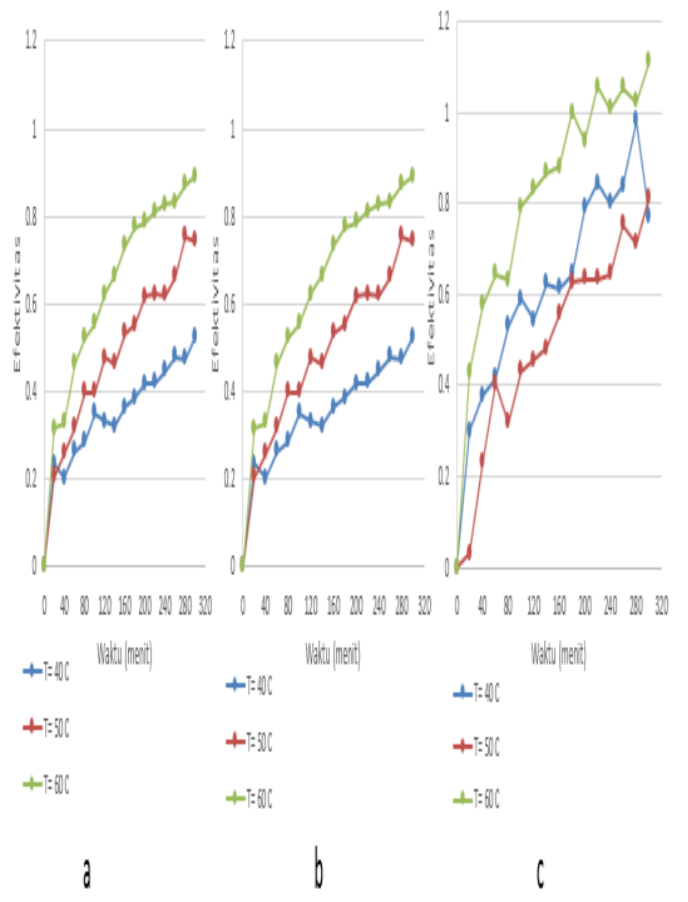

Gambar 12. Pengaruh konsentrasi larutan osmosis (a). 50 Brix, (b). 60 Brix, dan (c). 70 Brix terhadap efektivitas pada suhu perendaman yang bervariasi.

Gambar 12 merupakan hubungan pengaruh antara efektivitas dengan waktu, yang dipengaruhi oleh konsentrasi larutan gula pada suhu yang bervariasi. Pada Gambar 12 merupakan hubungan yang dipengaruhi oleh suhu $60^{\circ} \mathrm{C}$ dan konsentrasi 70 Brix (konsentrasi yang tertinggi), yang memiliki efektivitas yang paling tinggi. Hal tersebut terjadi karena adanya beda potensial yang tinggi pada 2 jenis konsentrasi larutan, yakni larutan di dalam bahan makanan yang rendah dan larutan di luar bahan makanan yang tinggi. Hal ini sesuai dengan penelitian yang dilakukan Wirawan dan Anasta (2013), yang menyatakan bahwa konsentrasi larutan memberikan pengaruh beda potensial dalam sistem dehidrasi osmosis. Jika beda potensial semakin tinggi, maka semakin cepat air yang keluar dari dalam bahan makanan. Pada Gambar 12 juga menunjukkan adanya bias pada data yang diperoleh, hal tersebut terjadi karena sampel 
yang digunakan selama pengukuran berbeda-beda.

\section{KESIMPULAN}

\section{Kesimpulan}

1. Perlakuan interaksi antara suhu $60^{\circ} \mathrm{C}$ dan konsentrasi larutan osmosis 70 Brix menghasilkan kadar air yang paling rendah yakni sebesar $33.5928 \%$ basis basah, Weight Reduction (WR) yang paling tinggi yakni sebesar 1.1947 dan efektivitas yang paling tinggi yakni sebesar 1.1116.

2. Perlakuan suhu $60^{\circ} \mathrm{C}$ secara individu menghasilkan Solid Gain (SG) yang paling rendah sebesar $2.7932 \mathrm{~g}$ dan perlakuan konsentrasi larutan gula 60 Brix secara individu menghasilkan Solid Gain (SG) yang paling rendah yakni sebesar $2.8308 \mathrm{~g}$.

3. Perlakuan konsentrasi larutan gula 70 Brix secara individu menghasilkan Water Loss (WL) yang paling tinggi sebesar $1.1693 \mathrm{~g}$.

\section{DAFTAR PUSTAKA}

Chavan, U.D. and Amarowicz R. 2012. Osmotic Dehydration Process for Preservation of Fruits and Vegetables. Canadian Center of Science and Education: Kanada.

Food and Agriculture Organization (FAO). 2017. Banana Market Review 2015-2016. Roma.

Jalali, V.R.R., Narendra N. and Gabriel F.D.S. 2008. Effect of Osmotic Predehydration on Drying Characteristics of Banana Fruits. UFS: Brasil.

Gaikwad, M.D., S.K. Jain, P.D. Jawake, L.K. Murdia, H.K. Jain and S.S. Lakhanal. 2016. Effect of Process Parameters on Osmotic Dehydration of Guava slices. M. Puat: India.

Herdiyantoro, Diyan. 2013. Rancangan Faktorial Rancangan Acak Lengkap dan Rancangan Acak Kelompok. Universitas Padjadjaran: Bandung.
Hijriani, Astria, Kurnia Muludi dan Erlina Ain Andini. 2016. Implementasi Metode Regresi Linier Sederhana pada Penyajian Hasil Prediksi Pemakaian Air Bersih PDAM Way Rilau Kota Bandar Lampung dengan Sistem Informasil Geografis. Universitas Lampung: Lampung.

Kartika, Priska Nur dan Fithri Choirun Nisa. 2015. Studi Pembuatan Osmodehidrat Buah Nanas (Ananas Comosus L. Merr): Kajian Konsentrasi Gula Dalam Larutan Osmosis Dan Lama Perendaman. Universitas Brawijaya: Malang.

Magdalena, Astri, Sri Waluyo dan Cicih Sugianti. 2014. Pengaruh Suhu dan Konsentrasi Larutan Gula Terhadap Proses Dehidrasi Osmosis Buah Waluh (Cucurbita Moschata). Universitas Lampung: Lampung.

Prabawati, Sulusi, Suyanti dan Dondy A Setyabudi. 2008. Teknologi Pascapanen dan Teknik Pengolahan Buah Pisang. Balai Besar Penelitian dan Pengembangan Pascapanen Pertanian: Bogor.

Sankat, C.K. and Mujaffar, S. 2006. Modelling the drying behaviour of salted catfish fillets. 15th International Drying Symposium. Budapest, Hungary.

Sastrosupadi, Adji. 2000. Rancangan percobaan praktis bidang pertanian. PT. Kanisius: Yogyakarta.

Saragih, Eka Febriana. 2016. Pengaruh Pupuk Cair Kulit Pisang Kepok (Musa paradisiaca forma typica) terhadap pertumbuhan tanaman sawi caisim (Brassica juncea L.). Universitas Sanata Dharma: Yogyakarta.

Singh, B., Panesar P.S. and Nanda V. 2008. Osmotic dehydration kinetics of carrot cubes in sodium chloride solution. International Journal of Food science \& Technology, 43, 1361 - 1370.

Sohibulloh, Imron, Darimyya hidayati dan Burhan. 2013. Karakteristik Manisan 
Nangka kering dengan perendaman

gula bertingkat. Universitas Trunojoyo Madura: Madura.

Sharma, S.K., Steven J.M. and Syed S.H.R. 2000. Food Process Engineering: Theory and Laboratory Experiments. Wiley-Interscience: New York.

Wirawan, Sang Kompiang dan Natalia Anasta. 2013. Analisis Permeasi Air Pada Dehidrasi Osmosis Pepaya (Carica Papaya). Universitas Gadjah Mada: Yogyakarta.

Witono, Judy Retti B., Y.I.P. Arry Miryanti dan Lia Yuniarti. 2013. Studi Kinetika Dehidrasi Osmotik Pada Ikan Teri Dalam Larutan Biner Dan Terner. Universitas Katolik Parahyangan: Parahyangan. 